\title{
Vil sette pasienten i sentrum
}

Det viktigste helsepolitiske temaet foran høstens valg er, paradoksalt nok, igjen å sette pasienten i sentrum. Vi må se hele pasienten og gi behandling ut fra medisinske behov og ut fra den enkeltes situasjon. Helsepersonell må få jobbe ut fra sin yrkesetiske stolthet. Det trengs en verdimobilisering i helsetjenesten.

Siden Stoltenberg I-regjeringens sykehusreform i 2001 er sykehusene blitt styrt mer som bedrifter, og pasientbehandling og omsorg er blitt mer som produksjon. Behandling av syke mennesker i krise, sjokk, sorg, men også i spenning, håp og glede, kan aldri bli produksjon av varer man skal tjene penger på. Hvert menneske skal møtes med håp og faglig dyktighet.

Sykehusene har tøffe budsjettkrav, og ledelse og ansatte må gjøre vanskelige prioriteringer hver eneste dag. Det er på flere områder lange ventetider, og det er store etterslep på vedlikehold, utstyr og IKT. Kristelig Folkeparti mener helsetjenestene må organiseres og finansieres for pasientens beste.

\section{Politisk styring av sykehusene}

Kristelig Folkeparti vil ha sterkere politisk styring av sykehusene ut fra medisinskfaglige, demografiske og geografiske forhold. Vi vil hindre at det er økonomi som først og fremst blir styrende for behandlingen som gis, hvilke sykehustjenester vi skal ha, og hvor de skal utføres. Vi vil innføre en årlig helse- og sykehusplan som behandles i Stortinget. Planen skal gi tydelige politiske prioriteringer og økonomiske rammer. Planen må se spesialisthelsetjenesten og kommunehelsetjenesten som en helhet. En viktig del av planen skal være helsebygg, både vedlikehold og utbygging. Vi foreslår at helsebygg forvaltes i en egen organisasjon.

$\mathrm{Vi}$ ønsker fortsatt statlig styring av sykehusene fordi det vil sikre likeverdige helsetjenester i hele landet, men vi vil legge ned de regionale helseforetakene. I dag er det for store forskjeller i helsetilbudet mellom regionene. De regionale helseforetakene utgjør et unødvendig byråkratisk mellomledd nå som antall lokale helseforetak er halvert fra om lag 40 til nærmere 20. Helseog omsorgsdepartementet må ivareta den nasjonale styringen av sykehusene. Lokal styring er en oppgave for de lokale helseforetakene.
Kristelig Folkeparti ønsker en sterk offentlig helsetjeneste. Private aktører kan komme inn på de fleste områdene i helseog omsorgstjenesten, så lenge de bidrar som et tillegg og ikke blir en konkurrent til det offentlige tilbudet. Vårt parti foretrekker

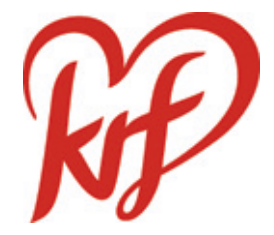

ideelle aktører, fordi disse ikke har profitt som mål, men tar eventuelt overskudd inn i driften og bidrar til å øke kvaliteten på tjenestene.

Sykehusene må organiseres og finansieres ut fra pasientens behov. Vi må prioritere de mest trengende, og det som gir mest helse. Vi må utnytte mulighetene ny teknologi gir til å løse sykehusenes oppgaver på nye, trygge og effektive måter. Et godt eksempel er mobil røntgentjeneste fra sykehus, som for mange sykehjemspasienter er mer pasientvennlig, billigere og mer effektivt enn å ta røntgen på sykehuset. I dag er finansieringsordninger og organisering til hinder for utbredelse av denne tjenesten.

Åtte år med rødgrønt flertallsstyre truer tilliten til norske sykehus. Mange pasienter og ansatte har betalt en høy pris. Kristelig Folkeparti vil bevare tilliten til helsetjenesten.

\section{Kommunehelsetjenesten}

Også i kommunehelsetjenesten må pasienten settes i sentrum. Det skal ikke handle om hvor mange millioner kroner kommunene har brukt på utskrivningsklare pasienter eller kommunal medfinansiering av sykehus- behandling. Kristelig Folkeparti vil særlig styrke kvaliteten på helsetjenestene til de sykeste eldre, både de som bor hjemme og de som bor på sykehjem. Mange er sårbare mennesker i livets siste fase og blir ofte kasteballer mellom sykehuset og kommunen. Mange har flere behandlingstrengende diagnoser og behov for individuelt tilrettelagt diagnostikk, behandling og omsorg. Vi må legge til rette for at det kan skje hos fastlegen og i sykehjemmene, gjennom faste stillinger for sykehjemsleger. Vi må ha god rekruttering av allmennleger, satse på forskningsog utviklingsarbeid og gode IKT-løsninger.

Allmennlegers kompetanse må ivaretas og brukes. Det er viktig å utvikle gode standarder og metoder for samarbeidet mellom hjemmetjeneste, rehabiliteringstjeneste og fastleger, slik metoden Helhetlige pasientforløp i hjemmet, utviklet av blant andre Anders Grimsmo, innebærer.

Kristelig Folkeparti vil satse på forebygging, tidlig innsats og rehabilitering. Dette gjelder ikke bare innen eldreomsorgen, men også innen rus og psykisk helse. Det er nødvendig med en opptrappingsplan for rehabilitering. Hver enkelt må få mulighet til å bruke egne ressurser.

\section{Line Henriette Hjemdal}

line.hjemdal@stortinget.no

Line Henriette Hjemdal (f. 1971) er stortingspolitiker fra Kristelig Folkeparti, medlem av Helse- og omsorgskomiteen og Kristelig folkepartis helsepolitiske talsperson.

Mottatt 28.6.2013 og godkjent 1.7.2013. Medisinsk redaktør Merete Kile Holtermann. 